\title{
NON INCREASED NEURON-SPECIFIC ENOLASE CONCENTRATION IN CEREBROSPINAL FLUID DURING FIRST FEBRILE SEIZURES AND A YEAR FOLLOW-UP IN PEDIATRIC PATIENTS
}

\author{
ALBERTO J. DORTA-CONTRERAS* EDITH TABIOO-VALDÉS* ALINA TABIOO-VALDÉS*, \\ CARIDAD DELGADO-FERNÁNDEZ* HANSOTTO REIBER**
}

\begin{abstract}
Febrile seizures are the commonest acute neurological disorder of early childhood. Studies suggested that febrile seizures are previous acute events from a more serious neurological problem. Due to neuron-specific enolase is generally accepted as a marker for neuropathological processes in the brain, 16 pediatric patients were studied during their first seizures and a year after it. Neuron-specific enolase in cerebrospinal fluid and blood were analysed by an immune enzyme assay. Non pathological neuron-specific enolase values were obtained in both periods in the group of patients. There were no significative differences when paired series statistics test was performed with $95 \%$ of confidence. Neuron-specific enolase appears not to be a marker for febrile seizures because its concentration not be increased in cerebrospinal fluid in this group of patients.
\end{abstract}

KEY WORDS: febrile seizures, neuron-specific enolase, cerebrospinal fluid.

\section{No incrementos en la concentración de enolasa específica de neurona en el líquido cefalorraquídeo durante el primer ataque febril y al año en pacientes pediátricos}

RESÚMEN - Los ataques febriles constituyen el trastorno neurológico agudo más común en la infancia temprana. Existen estudios que sugieren que los ataques febriles son eventos agudos previos a problemas neurológicos más severos. Debido a que la enolasa específica de neurona está aceptada generalmente como marcador de procesos neuropatológicos en el cerebro, se estudiaran 16 pacientes pediátricos durante su primer ataque y al año de este. La enolasa específica de neurona en el líquido cefalorraquídeo y sangre fue analizada por una prueba inmunoenzimática. No se obtuvieron valores patológicos de enolasa específica de neurona en ambos períodos en el grupo de pacientes. No hubo diferencias significativas al aplicar el test de series apareadas con un $95 \%$ de confianza. La enolasa específica de neurona parece no ser un marcador para ataques febriles porque su concentración no se incrementa en este grupo de pacientes.

PALABRAS-CLAVE: ataques febriles, enolasa específica de neurona, líquido cefalorraquídeo.

Febrile seizures are the commonest acute neurological disorder of early childhood. Studies suggested that febrile seizures are previous acute events from a more serious neurological problem ${ }^{1,2}$. There are also risks of later epilepsy, continuing intellectual deficit and EEG abnormalities ${ }^{3,4}$. In these circumstances the initial febrile seizure appears to be just one event in a lifetime of neurological problems.

Neuron-specific enolase (NSE; EC 4.2.1.1) is generally accepted as marker protein for pathological process in the brain in adults 5 .

*Laboratorio Inmunología, Hospital Pediátrico San Miguel, Ciudad Habana, Cuba; **Neurochemisches Labor, Neurologischen Klinik, Georg-August University, Gottingen Germany. Aceite: 16-julho-1998.

Dr. Alberto J. Dorta-Contreras - Laboratorio Inmunología, Hospital Pediátrico San Miguel - Apartado 10049 CP 11000 Ciudad Haban - Cuba. 
A group of pediatric patients suffering from its first febrile seizures were followed-up a year later and during their acute phase. Non increased NSE concentration in cerebrospinal fluid (CSF) was observed. Increased NSE seems not to be a marker for the first febrile seizures in children.

\section{METHODS}

Sixteen pediatric patients, mean age 3 years, suffering from its first febrile seizure were included in the investigation. Consent for participation in this study was given by written permission by their parents. This study was approved by the local Scientific Committee and the Ethics Committee.

Simultaneous serum and CSF samples were obtained from all the patients in the acute phase. Both samples had been taken 30 minutes as average time after the febrile seizures.

This group of patients was followed-up monthly during one year after their first febrile seizure by the neuropediatric staff.

Eleven patients never repeated febrile seizure during the period. Among them, one patient suffered from a complex febrile seizure and two patients had risk factors associated with their first febrile seizures.

Three patients had recurrent febrile seizures during the year follow-up. Only two patients that began with febrile seizures were characterised as epileptic patients at the final stage of this study.

A year after their first seizure a second sample of serum and CSF were taken simultaneously to complete the investigation. Sera and CSF NSE were quantified by enzyme immunoassay EIA KIT (Hoffmann - La Roche, Basel $)^{6}$ with monoclonal anti-NSE antibodies and polyclonal anti-(anti NSE) IgG conjugate. The assay is specific for the gamma-subunit and also detects the alpha-gamma dimers.

Hemolytic blood samples were discarded (if hemoglobin according to dry test stripes, Heglostix, Bayer Diagnostic was 3 plus or more). Serum and CSF samples were stored frozen to be analysed in one series.

We compared the serum and CSF NSE levels of each patient with himself in the acute phase and a year later by the paired series statistical test. This test makes possible this "patient by patient" comparison to detect statistical differences of NSE levels during this period.

\section{RESULTS}

Serum samples of 105 apparently adult healthy volunteers showed the following values: $\mathrm{x} \pm$ $\mathrm{SD}=6.9 \pm 2.2 \mathrm{ng} / \mathrm{mL}$. The total range of values of the volunteers was $2.8-15.2 \mathrm{ng} / \mathrm{mL}$ with a $96 \%$ reference range of 3.3-13.3 ng/mL, excluding the four most extreme values.

NSE values were considered to be increased if the blood concentration was $>30 \mathrm{ng} / \mathrm{mL}$.

Figure 1 shows the NSE concentration in the blood and CSF of the patients with recurrent seizures, with complex febrile seizures, with febrile seizures with risk factors associated and the only two patients that was possible to classify as epileptic patients. We did not found increased NSE values in blood of the patients.

The patients that suffered its first febrile seizure with complexity and risk factors associated and those with a definitive diagnosis of epilepsy showed no increased NSE values (Fig 1).

Blood and CSF NSE levels in febrile seizures without a second episode of seizures had no significant changes between the acute phase and the second sample on year later (Fig 2).

No differences between serum NSE values were observed in patients during the acute phase and a year later according with the classification of the seizures and the treatment. Also, the levels of the patients without treatment showed no statistically differences with a $95 \%$ of confidence (Table 1).

\section{DISCUSSION}

The analysis of NSE in blood represents the first blood parameter indicative for destructive processes in brain, but there is no sign available that the NSE is induced by these processes. The release of NSE from brain cells represents the actual amount of NSE present in the brain cells at any time. 


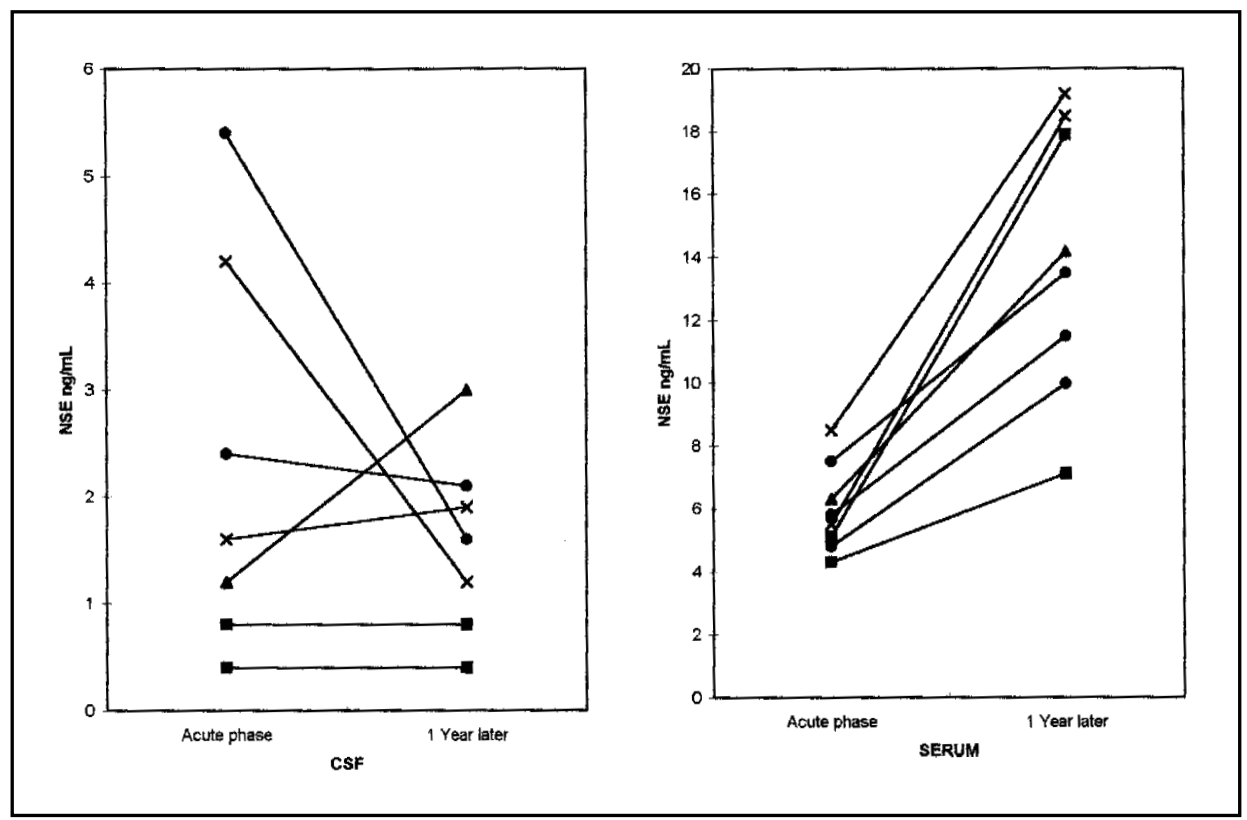

Fig 1. NSE concentration in blood and CSF of the patients with recurrent febrile seizures $(\mathrm{m})$, with complex febrile seizures (s), with febrile seizures with risk factors associated (1) and with epilepsy (X). There are not significant variation.

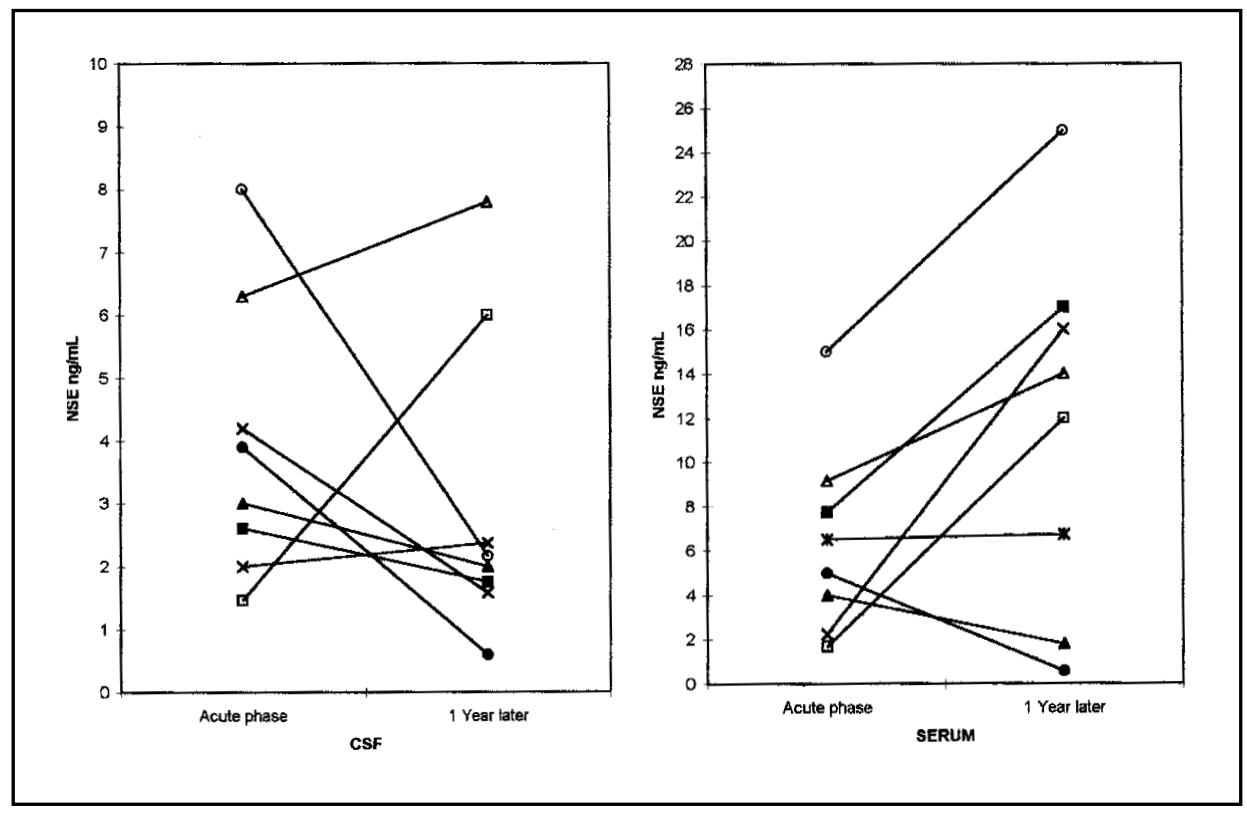

Fig 2. NSE concentration in blood and CSF of the patients with febrile seizures. Each different symbol means a patient. No significant statistic variation was observed. 
Table 1. Serum NSE variation with seizure evaluation and treatment.

\begin{tabular}{|c|c|c|c|c|c|c|}
\hline & $\begin{array}{l}\text { Mean value } \\
\text { NSE acute } \\
\text { phase ng/mL }\end{array}$ & $\begin{array}{l}\text { Mean value } \\
\text { NSE } 1 \text { year } \\
\quad \text { later }\end{array}$ & $\begin{array}{l}\text { Mean value } \\
\text { individual } \\
\text { differences } \\
\text { (d) }\end{array}$ & $\begin{array}{c}\text { Calculate } \\
\text { value } \\
\mathrm{T}\end{array}$ & Table value & Significance \\
\hline $\begin{array}{l}\text { Recurrent febrile } \\
\text { seizures }\end{array}$ & 3.755 & 1.58 & 2.215 & 0.5 & $\mathrm{~T}_{0.05}^{2}=4.303$ & NS \\
\hline $\begin{array}{l}\text { Febrile seizures } \\
+ \text { risk factors }\end{array}$ & 1.55 & 1.045 & 0.51 & 0.89 & $\mathrm{~T}^{1}{ }_{0.05}=12.7$ & NS \\
\hline $\begin{array}{l}\text { Febrile seizure } \\
+ \text { epilepsy }\end{array}$ & 3.55 & 1.66 & 1.15 & 0.52 & $\mathrm{~T}^{1}{ }_{0.05}=12.7$ & NS \\
\hline Febrile seizure & 3.327 & 2.834 & 2.31 & 0.33 & $\mathrm{~T}_{0.05}^{7}=2.306$ & NS \\
\hline \multicolumn{7}{|c|}{ NSE variation according with treatment } \\
\hline Phenobarbital & 2.505 & 4.9 & 2.201 & 1.34 & $\mathrm{~T}_{0.05}^{2}=4.303$ & NS \\
\hline Phenytoin & 3.05 & 1.65 & 1.4 & 0.508 & $\mathrm{~T}_{0.05}^{1}=12.70$ & NS \\
\hline Without treatment & 3.1 & 2.505 & 1.978 & 0.27 & $\mathrm{~T}_{0.05}^{10}=2.228$ & NS \\
\hline
\end{tabular}

NSE levels in normal and sick children is not known so far. Nevertheless we compared each patient with himself and there are no differences of NSE levels in patients suffering from only one febrile seizure episode one year after the crisis. Also there are no differences in the two patients that had epilepsy and the three ones that had been suffering from recurrent febrile seizures during the year under study.

In adults, if the time after the epileptic seizures is less than six days increased NSE values are usually reported. But in the present study the second lumbar puncture to obtain CSF was taken during a period without epileptic seizures. The last crisis before the second lumbar puncture was more than 15 days average in all the cases. So in reality we did not obtain a sample near a crisis for these chronic patients.

Recent papers suggested that NSE in CSF have a potential as disease-unspecific marker for the neuronal degeneration in chronic processes like demential disorders and may be used as possible prognostic indicators in Guillian-Barré syndrome ${ }^{7,8}$. All types of organic brain diseases including transitory ischemic attack or epileptic seizures can lead to unspecific increases of NSE values in $\mathrm{CSF}^{9}$.

There are five patients treated with antiepileptic drugs: three patients were treated with phenobarbital and two patients with phenytoin. Phenobarbital has been noted to increase the threshold for febrile seizures in rat pups ${ }^{10,11}$ and in mice ${ }^{12}$. Phenytoin, on the other hand, may either decrease the threshold ${ }^{10}$ for febrile seizures in rats ${ }^{11}$.

In our group of pediatric patients with anticonvulsive treatment no NSE variation was observed in comparison with those who were not treated at all.

In addition there are no evidences the first febrile seizure causes structural brain damage but clinically it was observed that some patients that never suffer from another crisis have neurological sequelae.

On the other hand, there are no data available about the concentration and duration of blood and CSF NSE release in children associated with seizures in the course of febrile illness ${ }^{13}$. 
There is an evident relationship between hypoxia of the brain and the seizures, with the consequent NSE release. A recent paper ${ }^{14}$ shows that the time course falling traumatic brain injury without an additional hypoxia is represented by a fast decay of the initially high NSE concentration within 10 hours and indicate a short-lasting irrigation with damage of neurons.

In our cases, if the NSE levels were increased in comparison with the unknown normal levels during the febrile seizures, the comparison with the same patient without another crisis a year later has to be statistically different.

These findings suggest that in the first febrile seizure in children NSE was not significantly released into CSF and NSE concentration in both biological fluids was not increased.

\section{REFERENCES}

1. Wallace SJ. The child with febrile seizures. London: Wright, 1998.

2. Ellenber JH, Nelsen JJ. Febrile seizure and later intellectual performance. Arch Neurol 1978;35:17-21.

3. Aicardi J, Chevrie JJ. Febrile convulsions: neurological sequelae and mental retardation. In Brazier MAB, Coceani F (eds). Brain dysfunction in infantile febrile convulsions. New York: Raven, 1976:247-257.

4. Gundel A, Doose H. Genetic patterns in febrile convulsions: a multivariate analysis. Neuropediatrics 1986;17:3-6.

5. Jacobi C, Reiber H. Clinical relevance of increased neuron specific enolase concentration in cerebrospinal fluid. Clin Chim Acta 1988; 177:49-54.

6. Reiber H, Fravendorf-Schaarschmidt H. NSE as a useful prognostic factor for patients after cerebral hypoxia. In Evaluation report. Cobas NSE EIA. Basel: Hoffmann - La Roche, 1994:8-22.

7. Blennow K, Wallin A, Ekamn R. Neuron specific enolase in cerebrospinal fluid: a biochemical marker for neuronal degeneration in dementia disorders? J Neurol Transm 1994,8:27-30.

8. Mokuno K, Kiyosawa K, Sugimura K, et al. Prognostic value of cerebrospinal fluid neuron specific enolase and S-100 b protein in Guillain-Barré syndrome. Acta Neurol Scand 1994;89:27-30.

9. Shaarschmidt H, Prange H, Reiber H. Neuron specific enolase concentration in blood as a prognostic parameter in cerebrovascular diseases. Stroke 1994;24:558-565.

10. Millichap JG. Febrile convulsions. Nwe York: MacMillan, 1968.

11. Olson JE, Scher MS, Holtzman D. Effects of anticonvulsivants of hypertemic-induced seizures in the rat pup. Epilepsia 1984;25:96-99.

12. Julien RM, Fowler GW. A comparative study in efficacy of newer antiepileptic drugs on experimentally induced febrile convulsions. Neuropharmacology 1977;16:719-724.

13. Meldrum BS. Secondary pathology of febrile and experimental convulsion. In Brazier MAB, Coceani F (eds). Brain dysfunction in infantile febrile convulsions. New York: Raven, 1976:231-239.

14. Thomas RS, Adler L, Reiber H. Release of neuron specific enolase following electroconvulsive therapy. J Neurochem (Submitted). 